\title{
Geluk vinden zonder het te zoeken
}

\author{
L. Annemans \\ 240 blz., Gent: Borgerhoff \& Lamberigts, 2021 (ISBN 978-94-6393-509-8)
}

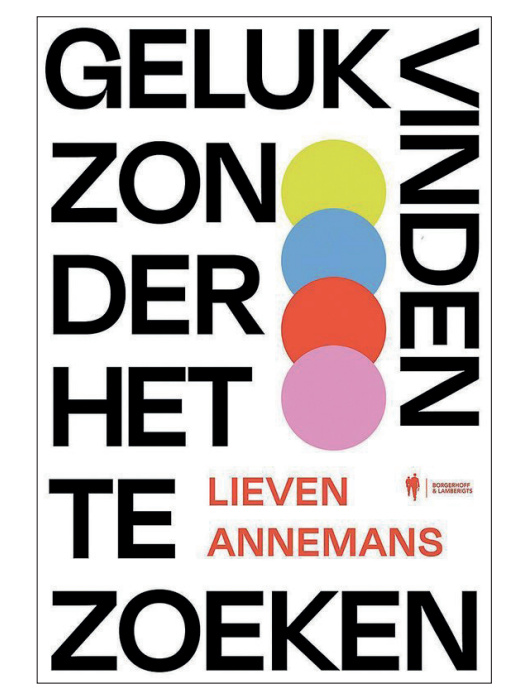

De auteur van dit boek is Vlaanderens bekendste en meest flamboyante gezondheidseconoom. De vraag die men zich als lezer dan ook meteen stelt, is: "Waarom schrijft een gezondheidseconoom een boek over de zoektocht naar geluk?” Het antwoord wordt per direct uitgelegd in het tweede hoofdstuk. Al jaren leidt de auteur aan de UGent een onderzoeksproject naar publiek en individueel welzijn, hij noemt zichzelf dan ook geen 'gezondheidseconoom' meer, maar een 'welzijnseconoom'. De ervaringen en de resultaten uit dit onderzoek plaatst hij in dit boek in een breder perspectief. Gecombineerd met zijn vlotte vertelstijl, begrijpelijke taalgebruik en talloze oneliners die nauwgezet de geijkte kernpunten accentueren, voelt de lezer zich rechtstreeks aangesproken door hem alsof men pal in een van zijn hoorcolleges is beland.

Hoewel het boek gericht is aan een breed publiek en dus niet louter de medische wereld beoogt, bevat het wel degelijk waardevolle leer- en reflectiemomenten voor de arts (in spe) en andere zorgverstrekkers. Vooreerst is er de uitleg over de methodiek van studies naar geluk en welzijn. Geluk kan dus inderdaad gemeten worden, meer zelfs: het Federaal Planbureau gebruikt rationeel deze empirisch vastgelegde informatie voor de planning van zorg op nationaal niveau. Hieruit mag duidelijk blijken dat welzijn niet hetzelfde is als gezondheid, status, vermogen of macht en ook niet louter als individu kan worden beleefd, maar steeds - rechtstreeks en onrechtstreeks - in wisselwerking met anderen. Een uiterst belangrijke boodschap voor de arts, zeker het type topdokter dat zichzelf graag het imago van redder der mensheid toe-eigent.

Het boek is zeer actueel, zoals geillustreerd aan de hand van talloze besprekingen over de impact van de Covid-pandemie, de lockdown en de heropstart op het welzijnsgevoel van de Belg. Voor de nuchtere cijferaar, waartoe ik mezelf reken, bevat het boek tevens interessante weetjes over de mens als biologisch wezen: hoeveel Belgen voelen zich (on)gelukkig en hoe zit dat in andere landen?, hoe verhouden positieve emoties/ ervaringen zich versus negatieve?, quid nature versus nurture? en hoe is dit alles geassocieerd met ziekte en levensverwachting? De auteur reikt ook - heel subtiel - zeer relevante, maar concrete gegevens aan over de impact van materiële welvaart: welk inkomen biedt de meeste kans op een hoge beleving van geluk/welzijn? In bloot cijfermateriaal toont hij dat overvloed ongelukkig maakt, net zoals armoede dat doet: heel mooi om te zien hoe het spectrum tussen deze twee extremen verloopt. Wie deze informatie bekijkt tegen de huidige 


\section{tvgg. wameses}

nood aan hervorming van de organisatie en de financiering van de Belgische gezondheidszorg én dit koppelt aan de actuele vraag tot concrete maatregelen ter preventie van burn-out en andere gezondheidsperikelen bij de arts/gezondheidswerker, weet wie hier wordt aangesproken. Dit verantwoordt ruimschoots deze boekbespreking in TvGG.

Verder bevat dit boek voor ieder wat wils: psychologie, sociologie, filosofie, spiritualiteit, enz. Het komt allemaal aan bod. In deze doet de auteur misschien iets te veel zijn best om Jan en alleman te behagen, want een zelfverklaard boek "voor iedereen die de wereld beter wil maken" kan net de brug te ver zijn.

Hoe dan ook, dit is een goed boek dat aangenaam en vlot leest, ontspannend en leerrijk is, met een relevante en niet te miskennen boodschap voor iedere geïnteresseerde lezer, al dan niet medisch geschoold. Het is een ideaal boek ter lectuur op een zomeravond op een terras met een koele pint, in de schaduw van het tuinprieeltje of aan het zwembad. Zij die hiervoor geen tijd hebben wegens werkdruk, blijven nog altijd interessant studiemateriaal.

W. Gyselaers

Hoofdredacteur TvGG 